\title{
Offending characteristics of male ex-armed forces personnel in prison
}

DOI:

10.1111/hojo.12189

\section{Document Version}

Accepted author manuscript

Link to publication record in Manchester Research Explorer

\section{Citation for published version (APA):}

Wainwright, V., Lennox, C., Mcdonnell, S., Shaw, J., \& Senior, J. (2017). Offending characteristics of male exarmed forces personnel in prison. The Howard Journal of Crime and Justice , 56(1), 19-33.

https://doi.org/10.1111/hojo.12189

\section{Published in:}

The Howard Journal of Crime and Justice

\section{Citing this paper}

Please note that where the full-text provided on Manchester Research Explorer is the Author Accepted Manuscript or Proof version this may differ from the final Published version. If citing, it is advised that you check and use the publisher's definitive version.

\section{General rights}

Copyright and moral rights for the publications made accessible in the Research Explorer are retained by the authors and/or other copyright owners and it is a condition of accessing publications that users recognise and abide by the legal requirements associated with these rights.

\section{Takedown policy}

If you believe that this document breaches copyright please refer to the University of Manchester's Takedown Procedures [http://man.ac.uk/04Y6Bo] or contact uml.scholarlycommunications@manchester.ac.uk providing relevant details, so we can investigate your claim.

\section{OPEN ACCESS}




\title{
Offending characteristics of male ex-armed forces personnel in prison
}

Verity Wainwright, Charlotte Lennox, Sharon McDonnell, Jenny Shaw and Jane Senior

\author{
University of Manchester
}

\begin{abstract}
Ex-armed forces represent the largest occupational subset of offenders in prison in England yet we know little about their offending behaviour. 105 veterans in prison were interviewed and their offending histories reviewed. Most were serving their first custodial sentence, predominantly for violent and sexual crimes and had previous convictions recorded: a number had offended before their service. High levels of alcohol misuse and pre-service adversity were found. There were significant differences between offence types: violent offenders were more likely than sexual or other offenders to have offended before service. Findings suggest interventions should focus on violent behaviour and alcohol misuse.
\end{abstract}

Keywords: ex-armed forces; offending; prison; anti-social behaviour; alcohol misuse; violence

\section{Introduction}

Concern for what happens to armed forces personnel when they leave service has been mounting in recent years, particularly in relation to their involvement in the criminal justice system (CJS) (Pemberton, 2010; Roberts, 2012; Wheeler, 2014). Whilst ex-armed forces personnel are less likely to offend than the general population, they are thought to make up the largest occupational subset of offenders in prison in England and Wales (Howard League, 2011). Widely varying estimates of the size of this group have been made, suggesting they account for between 3.5 and $16.75 \%$ of the prison population (Napo, 2008; Statistics at Ministry of Defence [MoD], 2010). However, such estimates are 
acknowledged as flawed and the exact number is unknown due to variable recording methods (Treadwell, 2010). Alongside conflicting estimates of the number of imprisoned ex-service personnel, little is known about their offending characteristics. Published in 2010 , a study undertaken by Statistics at MoD (formerly the Defence Analytical Services and Advice [DASA]), matched names on the MoD's service leaver database with prisoner records. They reported that imprisoned service personnel were predominantly male, ex-Army, British nationals and aged between $45-54$ years. The most common convictions were for violent and sexual offences.

Service experience itself, in particular the experience of deployment, is often thought to contribute to the offending behaviour of this group (Napo, 2009). Studies have found correlations between post-traumatic stress disorder (PTSD) and post-deployment violence and aggression. For example, MacManus, Dean, Al Bakir et al. (2012) found a strong association between combat and experiences of trauma with violence on homecoming amongst UK military personnel. Furthermore, co-morbidity of PTSD and alcohol misuse, and alcohol misuse alone, have been found to increase the risk of violence post-deployment (Elbogen et al., 2014; MacManus, Dean, Jones et al., 2013). Fontana and Rosenheck (2005) concluded that PTSD played a mediational role between warzone experience and post-service anti-social behaviour (ASB). In terms of recorded convictions, in their lifetime prevalence study of 13,856 serving and ex-service personnel, MacManus et al. (2013) found $16 \%$ of the sample had one or more offences recorded. Violent offences were the most common offence type and rates of offending were higher during post-deployment than either pre-deployment or preenlistment.

However, the report by the Howard League inquiry into former service personnel in prison also highlighted the roles of social isolation and exclusion and financial pressures as contributing to law breaking (Howard League, 2011). The offending behaviour of serving and ex-service personnel is likely to be multi-faceted. Many armed forces personnel, particularly Army recruits, come from disadvantaged backgrounds (Howard League, 2011). It is therefore possible that some ex- service 
personnel may have committed offences irrespective of their service. Fontana and Rosenheck (2005) found pre-service factors were the biggest determinant of anti-social behaviour (ASB) post-service. Because having criminal convictions is not necessarily a bar (each branch considers individual circumstances), personnel may have offended prior to their service. Indeed, in a sample of 10,272 UK military personnel, MacManus, Dean, Iversen et al. (2011) found $18 \%$ were considered to have preenlistment ASB such as fighting at school, playing truant or getting into trouble with the police when growing up. They found an association between ASB and adverse outcomes such as alcohol misuse and fighting or assaultive behaviour, suggesting that those with such pre-service backgrounds are more likely to display negative behavioural outcomes.

Despite this knowledge, we know very little about the offending characteristics of ex-armed forces personnel in prison specifically. Although this group represent a minority of ex-armed forces personnel, their offending is different by the very fact they are in prison. Understanding more about this groups offending behaviour, and the factors that may have influenced their offending, can inform service provision for this group. Therefore, the aim of the current study was to describe the offending characteristics of a sample of male ex-armed forces personnel in prison and consider the factors that may have contributed to their offending behaviour such as any pre-service ASB and substance misuse.

\section{Method}

This study was conducted as part of a larger mixed methods study exploring the experiences and mental health needs of a sample of male ex-armed forces personnel in prison.

Sample and Procedure

Six prisons in England for adult men participated in the study. All identified ex-armed forces personnel who were in prison when the study began were approached to take part. Thereafter, over the course of 18 months, consecutive sampling ensured all newly received prisoners identified as ex-armed forces 
personnel were invited to take part. Potential participants were initially approached by the Veterans in Custody Support Officer (VICSO) ${ }^{1}$ at the prison. In total, one hundred and nineteen prisoners were approached; 14 (12\%) declined to take part, thus 105 were recruited to the study. Participants were interviewed in a private room within the prisons by the first author. A questionnaire was administered that collected demographic and background information, explored military experiences, and personal circumstances post- discharge for all participants. Standardised measures assessing participants' mental health and substance misuse were also employed.

The offending histories of participants were collated from official prison records. The following information was captured for each participant: whether they had any offences prior to service; number of previous convictions, broken down by category (i.e. violent, sexual, acquisitive); number of previous custodial sentences; age at first conviction; main current index offence; age at index offence; and whether new to custody, or transferred from another prison. Through self-report, information detailing any offending during service was gathered in an effort to capture offences dealt with by the military, rather than the civilian, CJS. Pre-service ASB was assessed using the measure of childhood adversity employed in Iversen, Fear, Simonoff et al.'s (2007) study. Participants were asked to respond 'true' or 'false' to 16 statements starting with 'When I was growing up...' The statements included both protective and adverse factors based on three domains of childhood exposures: family relationships, parenting and adolescent behaviour. The same criteria used by MacManus et al. (2011) in their study of pre-enlistment ASB amongst military personnel were adopted to provide some comparative context in which to discuss the findings. Therefore, participants were classed as having pre-enlistment ASB if they answered 'true' to 'I used to get into physical fights at school' in addition to at least one of the following three statements: 'I often used to play truant at school,' 'I was suspended or expelled from school,' and 'I did things that should have, or did get me, into trouble with the police.' Whilst not diagnostic criteria for conduct disorder, these criteria can be used as a marker for ASB they are at a similar threshold required to make a diagnosis (MacManus et al., 2011). 
All data were analysed using SPSS version 22. Descriptive statistics and frequencies are reported to describe the offending characteristics of the sample. Composite variables were developed to compare educational attainment (i.e. those who left school with no qualifications compared to those who achieved GCSE, or equivalent, minimum qualifications) and discharge status (those who left via an agreed method of termination of service such as natural end of contract or voluntary redundancy compared to those who had their service terminated early, such as a disciplinary discharge). In addition, to compare groups on substance misuse, participants were considered to have an alcohol misuse problem in the year prior to entering prison if they screened, using the Alcohol Use Identification Test (AUDIT; Babor, Higgins-Biddle, Saunders et al., 2001), as having harmful and/or hazardous use of alcohol (i.e. a score of 8) and/or a drug misuse problem if they screened positively (i.e. a score of $\geq 6$ ) on The Drug Abuse Screening Test (DAST; Skinner, 1982). Finally, to compare groups on the basis of PTSD, participants who met the subthreshold diagnosis cut-off of score of 40 (using the civilian version of the PTSD checklist [PCL-C; Blanchard, Jones-Alexander, Buckley et al., 1996]) were compared with those who did not.

Comparisons were made between three index offence types, categorised as: violent (including robbery), sexual, and other (i.e. drugs offences, theft offences) using the chi squared statistic and oneway ANOVA's (Post-hoc Tukey HSD tests were used to explore any significant group mean differences between groups and degrees of freedom and eta squared effect size are reported for one- way ANOVA's). Cramer's V level of association is reported for chi squared analyses. Comparisons were also made between those who screened as having pre-enlistment ASB and those who did not using independent samples $t$-tests and the chi squared statistic (degrees of freedom are reported for $t$-test comparisons and odds ratios for chi squared analyses).

\section{Ethics Statement}


All participants provided informed, written consent to take part in the study and for the research team to access healthcare and Police National Computer records held at the prison. Ethical approval was provided by a National Health Service (NHS) research ethics committee (13/WA/0332); the National Offender Management Service (2014-208) and the governor and healthcare provider at each participating prison.

\section{Results}

Sample characteristics

The sample of 105 male ex-armed forces personnel in prison had a mean age of 42 years (SD = 14; median $=41$; range $20-88$ ) and were predominantly of white British ethnicity (95\%). Most of the sample (60\%) had achieved GCSE, or equivalent, level of education, although a quarter (26\%) had left school with no qualifications. The service branch most represented was the Army (81\%), followed by the Royal Navy and Royal Air Force (RAF; 14\% and 5\% respectively), with the most common rank equivalent to Private (72\%). Most had experienced deployment (61\%) and their average service length was 6 years (median $=4 ; S D=5$ ), ranging between 1 and 30 years. Participants left the armed forces most commonly via three methods: $44 \%$ by end of service contract; $18 \%$ by premature voluntary release or sign-off; and 18\% via disciplinary discharge. In the year prior to entering prison, over half of the sample (56\%) screened positive for an alcohol misuse problem and $28 \%$ for a drug misuse problem. Twenty-four percent of the sample screened positively for a subthreshold diagnosis of PTSD.

\section{Prison and index offence characteristics}

Of the 105, 66 (63\%) were recruited to the study from local prisons; 22 (21\%) from training prisons; and 17 (16\%) from open prisons. The sample consisted of $12 \%$ remand (convicted and un-convicted) and $88 \%$ sentenced prisoners. The mean age at current conviction was 40 years old $(S D=14 ;$ range 20-86) and, for just over half of the sample (55\%), their current term was their first time in prison. The 
most common index offence type was for violence against the person (32\%). Table 1 shows the frequency of offence types. In terms of their index offence, 31 (30\%) participants reported that they considered alcohol to be a contributing factor and $15(14 \%)$ reported that drugs were a contributing factor.

\section{[Insert Table 1 about here]}

The index offence types detailed in table 1 were re-grouped for analysis purposes into violent, sexual and other offence type groups. The violent offending group contained offences with and without injury, and robbery ( $n=36 ; 34 \%)$; the sexual offending group combined the most serious and other sexual offenders ( $n=29 ; 28 \%)$; and all other offence types were grouped into the 'other' offence type $(n=40 ; 38 \%)$. Those with violent index offences were more likely to have had their service terminated, or to have been discharged, than those with sexual or any other type offences (table 2). Violent offenders were more likely to have screened positively for alcohol misuse in the year prior to entering prison than those with sexual or other index offence types and to have offended prior to service in the armed forces. Those with other index offence types were more likely to screen positively for drug misuse in year before entering prison than violent or sexual offenders.

There was a significant difference between offence groups for length of service. Post-hoc Tukey HSD tests revealed violent offenders were more likely to have shorter service lengths than sexual offenders (Mean Difference $=-3.83, p=.009$ ), however there were no significant differences between violent and other offence types. Whilst there was no significant difference regarding number of previous convictions between violent and other, or violent and sexual offenders, post-hoc tests showed that those with other index offence types were significantly more likely to have a higher number of previous convictions in comparison to sexual offenders (Mean Difference $=10.94, p=.035$ ). 
At the time of interview, sexual offenders were significantly older than violent (Mean Difference $=$ $12.70, p=.001$ ) or other (Mean Difference $=10.53, p=.004$ ) offenders. They were also significantly older when first convicted than either violent (Mean Difference $=16.40, p=.000$ ) or other (Mean Difference $=12.05, p=.004)$ offenders. There was no significant difference in age between violent or other offenders at either time of interview or first conviction.

\section{[Insert Table 2 about here]}

\section{Pre-enlistment ASB and previous offending}

Thirty-eight participants (36\%) reported having offended during their time in the armed forces; 10 (10\%) had spent time in military prison. Full offending histories were captured for 98 participants (93\%). For 7 (7\%) prison case records were incomplete and only partial histories were gathered. The mean age of the sample at the time of their first conviction was 28 years old ( $S D=16$; range 12-86). Most (70\%) had previous convictions, most commonly (29\%) having between one and five previous convictions. Convictions were most common for violent offences (28\%), followed by miscellaneous offences $(20 \%)$ and theft offences $(16 \%)$. Almost a third $(n=29 ; 30 \%)$ had offended before their service in the armed forces. Pre-enlistment ASB was evident in half (50\%) of the overall sample. Sixty-four percent reported often playing truant from school; $57 \%$ percent of the sample reported getting into physical fights; $56 \%$ reported doing things growing up that should have, or did, get them into trouble with the police; and $44 \%$ reported they had been suspended or expelled from school at some point.

Comparisons of those with pre-enlistment ASB and those without, are shown in table 3. Those with pre-enlistment ASB were more likely to be younger, both at the time of interview and at the age of their first conviction. Compared to those without pre-enlistment ASB, they were more likely to have 
left school with no qualifications, to report they had been convicted of an offence during their service in the armed forces and to screen positively for drug misuse in the year prior to entering prison.

\title{
[Insert Table 3 about here]
}

\begin{abstract}
Discussion
Ex-armed forces personnel in prison, in this study, were younger than those included in the earlier Statistics at MoD (2010) report. However, in common with Statistics at MoD findings, the sample was predominantly made up of ex-Army personnel and a similar proportion of sentenced versus remand prisoners was found. This study also echoes the finding that violent, sexual and drugs offences were the most common offence types in this group. For most, it was their first time in prison, although the majority had previous convictions, including a proportion who had offended prior to their service. More than a third of the sample reported having offended during their armed forces career.
\end{abstract}

Interestingly, there was no association between having experienced deployment and offence type. Given the previous finding of MacManus et al. (2012) of an association between combat and experiences of trauma with post-deployment violence, this may be a surprise. The focus on combat and experiences of trauma in MacManus et al.'s (2012) study may be key to an association with violence as opposed to deployment experience in general. Additionally in relation to previous work, although nearly a quarter of the sample screened positively for PTSD, we found no association between PTSD and offence type. Ex-armed forces personnel in prison in this study with violent index offences were no more likely than sexual or other offenders to have screened positively for PTSD. However, a difficulty with both this finding and that of deployment and offence type, is that due to the nature of the study we do not have the data to tell us when offending, particularly violent offending, took place in relation to deployment experience, nor when PTSD symptoms began or 
whether they are specifically 'combat-related'. This would add more depth to these preliminary findings.

In line with previous work, our findings do indicate that alcohol misuse does contribute to offending behaviour in ex-armed forces personnel in prison. The link between alcohol use and violence in particular has been recognised in both the general population (Graham \& Livingston, 2011) and military personnel (MacManus et al., 2013). Participants in this study with violent index offences were more likely to have screened positively for alcohol misuse in the year before entering prison than sexual or other offenders. Given that levels of alcohol misuse have been found to be substantially higher amongst armed forces personnel in comparison to the general population (Fear, Iversen, Meltzer et al., 2007; Fear, Jones, Murphy et al., 2010), and the high proportion of alcohol misuse within this sample overall, it is clearly a factor that needs to be considered in targeting the prevention of offending in this group. With the service provision for alcohol misuse in prison having been criticised (HM Inspectorate, 2010), services in custody likely need development for this need to be met.

Violent behaviour prior to service was reported by more than half the sample with a high proportion (57\%) reporting fighting often at school. Violent offences were not only the most common index offence type (ranging from assault to murder), but also the most commonly recorded previous offence type. Violent offences were also the most commonly self-reported offences by those who admitted to offending during service. Although most of the sample left the armed forces via agreed methods, those with a violent index offence were significantly more likely to have been discharged from service compared to sexual or other offenders. They were also more likely to have had shorter service lengths. However, the current study does not allow us to determine whether violent offending specifically was the cause of their discharge. This group was also more likely to have offended prior to service in the armed forces.

Violent and other offenders were found to be largely similar, but former service personnel imprisoned for sexual offences were found to have a number of differences in comparison to the two 
other groups. Sexual offences were the second most common index offence type in this study and in the analysis by Statistics at MoD (2010). Their analysis found that ex-armed forces personnel were less likely to be in prison than the general population for all offences except sexual offences, of which former service personnel were more likely to be in prison than the general population. Despite this finding we know very little about this type of offending by this group. The results of this study suggest that the offending characteristics, and the trajectory of offending, of this sub-group differ from those who committed violent or other types of offences.

Sexual offenders were significantly older than violent or other offenders at the time of interview and at their first conviction, possibly suggesting offending behaviour for this group began at a later age, or that they are being convicted of historical sexual offences. There has been an increase in sexual offences recorded by the police and they are at their highest number in over ten years (Office for National Statistics [ONS], 2016). However, the report cautions that this may not be an accurate representation of trends in sexual offending. They postulate that the increase is likely to be the result of improved recording of such offences by police and the increased willingness of victims to report sexual offences (ONS, 2016). Our results show that sexual offenders were the least likely to have offended before service and had the least number of previous recorded convictions in comparison to violent and other offenders. Of course our results are based on official records of convictions only, we are unable to know for certain whether the recorded offences for participants represent their full offending past. However, in a review of the general sex offender population, the Ministry of Justice (MoJ) (2013) reported that the majority of offenders sentenced for a sexual offence had not previously been cautioned or convicted in relation to previous sexual offences.

This group were also less likely to screen positively for an alcohol or drug misuse problem. We can only speculate on why this group are so distinct. It would be interesting to look more closely at the offending profile of this sub-group. For example, the profile of those who may have been convicted of historical sexual offences only is likely different to those ex-armed forces personnel who have been 
convicted for more recent sexual offences and/or who have offended during service. A larger sample size would allow for to stratify this group by age cohorts which may help to improve of understanding of this group further. Unfortunately our data do not tell us the exact nature of the offence (i.e. pornography, sexual assault, rape) or, where relevant, who the victim was (i.e. a stranger, partner, adult or child). However, $69 \%$ of offences by those who had committed a sexual index offence were categorised at the most serious level (including rape, sexual assault and sexual activity with children). Unpicking this further would provide us with key information. The classification of sexual offences typically differentiate between offences against children, and rape (Wilson \& Alison, 2005). Sexual offending has also been linked to adverse family backgrounds and attachment difficulties (Hanson \& Morton-Bourgon, 2005), which are features of ASB.

Childhood ASB has previously been linked to both ASB and crime in adulthood (Robins, 1978; Simonoff, Elander, Holmshaw et al., 2004). In this study, pre-enlistment ASB was evident in half of the sample, a higher prevalence than that found in MacManus et al.'s (2011) study. This could in part be due to the difference in sampling as this study focused on prisoners whereas MacManus et al. (2011) looked predominantly at serving military personnel. A high level of pre-enlistment ASB amongst military personnel has previously been linked, in part, to the recruiting practice of the armed forces (MacManus et al., 2011). It is generally believed that, traditionally the armed forces, particularly the Army, recruit from low socio-economic areas with many recruits coming from disadvantaged backgrounds and with low educational attainment (Fossey, 2010). Although only $11 \%$ of the current sample reported having problems reading and/or writing at school, and around a quarter (26\%) had left school without any qualifications, most reported having achieved a minimum of GCSE level education. However, this is based purely on self-report so may require interpreting with caution.

Those with pre-enlistment ASB were more likely to have offended during their service in the armed forces. This may suggest that those entering employment in the armed forces with pre-service ASB, may be more likely to continue on this trajectory or are less influenced by discipline inherent in 
the armed forces. As with the finding that violent offenders were more likely to have offended before service, this may raise the question that recruits with previous criminal justice involvement should not be able to join the armed forces. We would however caution that having offended before service or displaying pre-service ASB, does not necessitate that all personnel will go on to offend; indeed, service in the armed forces is more likely to improve the life courses of many, including those who may otherwise have become habitual criminals in civilian life. Ex-armed forces personnel in prison represent a minority of personnel who have not made a successful transition from military to civilian life, and in this group, the results of this study do suggest that pre-service offending may be an important determinant in their subsequent offending behaviour.

However, there was no association between pre-enlistment ASB and a higher number of previous convictions. Therefore, it may be reasonable to assume that additional factors play a role in the offending of former service personnel in prison. There was no association between pre-enlistment ASB and screening positively for alcohol misuse, but this group were more likely to have screened for drug misuse. Considering that ex-armed forces personnel in prison are less likely than the general prison population to report drug misuse (Kelly, 2014), this is an interesting finding. Given that drug misuse is a marker of ASB in general, perhaps this finding suggests that former service personnel with pre-service ASB are more likely to have a drug misuse problem.

The findings of this study add to existing work by providing a more detailed description of the offending characteristics of ex-armed forces personnel in prison than previously available. A strength of the study is that the military service of participants was verified, and official offending histories captured for the majority of the sample where records were available. Unfortunately, reports of military offending and pre-enlistment experiences and behaviour were measured using self-report and could be subject to recall bias. Another limitation is that we do not have comparative data for the wider prison population from which this sample was drawn. Therefore we are unable to assess the differences between the populations- this would have significantly strengthened the study. A 
prospective study may be particularly useful for this purpose. Furthermore, utilising a bigger sample size would allow for a more robust analysis of this group, and sub-groups within the population. With calls to improve the identification of former service personnel involved in the CJS (Phillips, 2014), this may be achievable for future research.

Nevertheless, our work has some important implications. Perhaps unsurprisingly, explanations for the offending behaviour of ex-armed forces personnel involved in the CJS must also take into account the influence of pre-service factors with the finding that, for some personnel, service in the armed forces acted as only an interruption in their offending behaviour. The results of this study also indicate that sexual offenders represent a characteristically different group of ex-armed forces personnel in prison. We currently know very little about this group and future research is needed to provide a more comprehensive understanding. Our findings also suggest that interventions aimed at targeting the offending behaviour of ex-armed forces personnel in prison should perhaps focus on violent and aggressive behaviour. Further, that tackling alcohol misuse amongst this group may also have the potential to reduce the risk of reoffending post-prison. There are existing programmes in prison to address such behaviour, but further work to understand their effectiveness with ex-armed forces personnel may be warranted. For instance, former service personnel, particularly those with combat experience, are likely to have been exposed to higher levels and different forms of violence compared to the general prison population. Indeed, even those personnel who do not experience deployment, are likely to have been trained in violence in preparation for conflict. Consideration regarding how services tackling violence and aggression and alcohol misuse are provided to former service personnel may also warrant additional thought. Previous literature has suggested that military awareness is important when supporting this group (e.g. Wainwright, McDonnell, Lennox et al., 2016). Further research is needed to assess the effectiveness of such interventions with ex-armed forces personnel in prison. 


\section{Notes}

1. A Veterans in Custody Support Officer (VICSO) is an officer in the prison who, usually, have also previously served in the armed forces themselves. They act as an identified point of contact for exarmed forces personnel to provide any necessary signposting.

\section{References}

Babor, T.F., Higgins-Biddle, J.C., Saunders, J.B. and Monteiro, M.G. (2001), AUDIT: The Alcohol Use Disorders Identification Test. Guidelines for Use in Primary Care, $2^{\text {nd }}$ Edition, World Health Organisation: Department of Mental Health and Substance Dependence.

Blanchard, E. B., Jones-Alexander, J., Buckley, T. C., \& Forneris, C. A. (1996). Psychometric properties of the PTSD checklist (PCL). Behaviour Research and Therapy, 34, 669-673.

Elbogen, E. B., Johnson, S. C., Wagner, H. R., Sullivan, C., Taft, C. T., Beckham, J. C. (2014). Violent behaviour and post-traumatic stress disorder in US Iraq and Afghanistan veterans. British Journal of Psychiatry, 204, 368-375.

Fear, N.T., Iversen, A., Meltzer, H., Workman, L., Hull, L., Greenberg, N., Barker, C., Browne, T., Earnshaw, M., Horn, O., Jones, M., Murphy, D., Rona, R.J., Hotopf, M. \& Wessely, S. (2007). Patterns of drinking in the UK Armed Forces. Addiction, 102, 1749- 59.

Fear, N.T., Jones, M., Murphy, D., Hull, L., Iversen, A.C., Coker, B., Machell, L., Sundin, J., Woodhead, C., Jones, N., Greenberg, N., Landau, S., Dandeker, C., Rona, R.J., Hotopf, M. \& Wessely, S. (2010). What are the consequences of deployment to Iraq and Afghanistan on the mental health of the UK armed forces? A cohort study. Lancet, 375, 1783-97.

Fontana, A. \& Rosenheck, R. (2005). The role of war-zone trauma and PTSD in the eitiology of antisocial behaviour. The Journal of Nervous and Mental Disease, 193(3), 203-209.

Fossey, M. (2010). Across the wire: Veterans, mental health and vulnerability. London: Centre for Mental Health. 
Graham, K. \& Livingston, M. (2011). The relationship between alcohol and violence: population, contextual and individual research approaches. Drug Alcohol Review, 30, 453-57.

Hanson, K.R. \& Morton-Bourgon, K.E. (2005). The Characteristics of Persistent Sexual Offenders: A Meta-Analysis of Recidivism Studies. Journal of Counselling and Clinical Psychology, 73, 1154-1163.

Howard League (2011), Report of the Inquiry into Former Armed Service Personnel in Prison. London: Howard League for Penal Reform.

Iversen, A.C., Fear, N.T., Simonoff, E., Hull, L., Horn, O., Greenberg, N., Hotopf, M., Rona, R. \& Wessely, S. (2007). Influence of childhood adversity on health among male UK military personnel. British Journal of Psychiatry, 191, 506-511.

Kelly, J (2014). Analytical Summary: The needs of ex-service personnel in the criminal justice system: Evidence from two surveys. London: Ministry of Justice.

MacManus, D., Dean, K., Al Bakir, M., Iversen, A.C., Hull, L., Fahy, T., Wessely, S. \& Fear, N.T. (2012). Violent behaviour in UK military personnel returning home after deployment. Psychological Medicine, $42,1663-1673$.

MacManus, D., Dean, K., Iversen, A.C., Hull, L., Jones, N., Fahy, T., Wessely, S. \& Fear, N.T. (2011). Impact of pre-enlistment antisocial behaviour on behavioural outcomes among UK military personnel. Social Psychiatry and Psychiatric Epidemiology, 47, 1353-1358.

MacManus, D., Dean, K., Jones, M., Rona, R.J., Greenberg, N., Hull, L., Fahy, T., Wessely, S. \& Fear, N.T. (2013). Violent offending by UK military personnel deployed to Iraq and Afghanistan: A data linkage cohort study. Lancet, 381, 907-917.

Ministry of Justice. (2013). An overview of sexual offending in England and Wales. London: Ministry of Justice.

Napo (2008). Ex-Armed Forces Personnel and the Criminal Justice System. London: Napo. 
Napo (2009). Armed Forces and the Criminal Justice System. London: Napo.

Office for National Statistics. (2016). Crime in England and Wales: year ending March 2016. London: ONS.

Pemberton, M (2010). Too many ex-servicemen end up in prison. The Telegraph. Retrieved $4^{\text {th }}$ November 2015 from:

http://www.telegraph.co.uk/lifestyle/wellbeing/maxpemberton/6951293/Too-many-ex-servicemenend-up-in-prison.html

Phillips, S. (2014). Former members of the armed forces and the criminal justice system: a review on behalf of the secretary of state for justice. London: Ministry of Justice.

Roberts, G (2012). One in 10 prisoners is a former soldier, new research reveals. The Independent. Retrieved $4^{\text {th }}$ November 2015 from: http://www.independent.co.uk/news/uk/crime/one-in-10prisoners-is-a-former-soldier-new-research-reveals-7944479.html

Robins, L.N. (1978). Sturdy childhood predictors of adult antisocial behaviour: replications from longitudinal studies. Psychological Medicine, 8, 611-622.

Simonoff, E., Elander, J., Holmshaw, J., Pickles, A., Murray, R. \& Rutter, M. (2004). Predictors on antisocial personality: Continuities from childhood to adult life. British Journal of Psychiatry, 184, 118127.

Skinner, H.A (1982). The drug abuse screening test. Addictive Behaviour, 7, 363-371.

Statistics at MoD (2010). Estimating the proportion of prisoners in England and Wales who are exArmed Forces - further analysis. London: Ministry of Defence.

Treadwell, J (2010). Counterblast: More than Casualties of War? Ex-military personnel in the Criminal Justice System. The Howard Journal, 49, 73-77. 
Wainwright, V., McDonnell, S., Lennox, C., Shaw, J. \& Senior, J. (2016). Treatment barriers and support for male ex-armed forces personnel in prison: professional and service user perspectives. Qualitative Health Research. Advance online publication. DOI: 10.1177/1049732316636846.

Wheeler, C (2014). Bid to cut number of war veterans in jail. Daily Express. Retrived $4^{\text {th }}$ November 2015 from: http://www.express.co.uk/news/uk/548086/New-prison-guidance-help-war-veteransjail-targeted-programmes

Wilson, G. \& Alison, L. (2005). Suspect prioritization in the investigation of sex offences: from clinical classification and profiling to pragmatism. In: L Alison (ed.), The Forensic Psychologist's Casebook: psychological profiling and criminal investigation. Devon, UK: Willan Publishing. 
Tables

TABLE 1

Index offence types of the sample $(n=105)$

\begin{tabular}{ll}
\hline Index offence & $\mathbf{N ~ ( \% )}$ \\
\hline Violence against the person+ & $34(32)$ \\
With injury & $26(77)$ \\
Without injury & $8(24)$ \\
\hline Sexual offences & $29(28)$ \\
Most serious* & $20(69)$ \\
Other & $9(31)$ \\
\hline Drugs offences & $16(15)$ \\
\hline Miscellaneous^ & $9(9)$ \\
\hline Burglary & $6(6)$ \\
\hline Other theft offences & $4(4)$ \\
\hline Fraud and forgery & $4(4)$ \\
\hline Robbery & $2(2)$ \\
\hline Offences against vehicles & $1(1)$ \\
\hline
\end{tabular}

+Violence against the person with injury includes all incidents of wounding and assault resulting in injury/death and without injury includes all violent incidents not resulting in injury; *Includes rape, sexual assault, and sexual activity with children; ${ }^{\wedge}$ Includes offences related to police, courts, prisons and driving offences. 
TABLE 2

Comparison of those with violent index offences $(n=34)$ with those with sexual $(n=29)$ and other $(n$ $=42$ ) index offence types

\begin{tabular}{|c|c|c|c|c|c|}
\hline Variable & Violent IO & Sexual 10 & Other 10 & $\chi^{2}(V)$ & $\mathbf{F}$ (d.f.; $\eta^{2}$ ) \\
\hline $\begin{array}{l}\text { Pre-service ASB, } n \\
(\%)\end{array}$ & $20(56)$ & $10(35)$ & $22(55)$ & $3.63(.186)$ & - \\
\hline $\begin{array}{l}\text { Left school with no } \\
\text { qualifications, } n(\%)\end{array}$ & $12(33)$ & $3(10)$ & $12(30)$ & $5.07(.220)$ & - \\
\hline $\begin{array}{l}\text { Convicted of an } \\
\text { offence whilst } \\
\text { serving, } n(\%)\end{array}$ & $13(36)$ & $8(28)$ & $17(43)$ & $1.62(.124)$ & - \\
\hline $\begin{array}{l}\text { Experience of } \\
\text { deployment, } n(\%)\end{array}$ & $20(56)$ & $20(69)$ & $24(60)$ & $1.24(.109)$ & - \\
\hline $\begin{array}{l}\text { Discharged from } \\
\text { service, } n(\%)\end{array}$ & $16(44)$ & $2(7)$ & $11(28)$ & $\begin{array}{c}11.33^{* *} \\
(.328)\end{array}$ & - \\
\hline $\begin{array}{l}\text { Positive alcohol } \\
\text { screen, } n(\%)\end{array}$ & $26(72)$ & $9(31)$ & $24(60)$ & $\begin{array}{c}11.45^{* *} \\
(.330)\end{array}$ & - \\
\hline $\begin{array}{l}\text { Positive drug } \\
\text { misuse screen, } n \\
(\%)\end{array}$ & $10(28)$ & $0(0)$ & $19(48)$ & $\begin{array}{c}18.98^{* *} \\
(.425)\end{array}$ & - \\
\hline $\begin{array}{l}\text { Positive PTSD } \\
\text { screen, } n(\%)\end{array}$ & $12(46)$ & $5(19)$ & $9(35)$ & $2.41(.151)$ & - \\
\hline $\begin{array}{l}\text { Offended before } \\
\text { service^}^{\wedge}, n(\%)\end{array}$ & $17(50)$ & $2(7)$ & $10(29)$ & $\begin{array}{c}13.98^{* *} \\
(.378)\end{array}$ & - \\
\hline \multicolumn{6}{|l|}{ Age, years } \\
\hline Mean (s.d.) & $37(11)$ & $50(15)$ & $40(14)$ & - & $8.31^{* *}$ \\
\hline $\begin{array}{l}\text { Median (min- } \\
\text { max) }\end{array}$ & $36(23-59)$ & $48(24-88)$ & 37 (20-79) & & $(2 ; 0.14)$ \\
\hline \multicolumn{6}{|l|}{$\begin{array}{l}\text { Age at first } \\
\text { conviction, years^}\end{array}$} \\
\hline Mean (s.d.) & $22(9)$ & $38(20)$ & $26(14)$ & - & $10.27^{* *}$ \\
\hline $\begin{array}{l}\text { Median (min- } \\
\text { max) }\end{array}$ & $20(12-50)$ & $31(12-86)$ & $21(14-77)$ & & $(2 ; 0.17)$ \\
\hline \multicolumn{6}{|l|}{$\begin{array}{l}\text { Number of } \\
\text { previous } \\
\text { convictions+ }\end{array}$} \\
\hline Mean (s.d.) & $14(18)$ & $4(6)$ & $14(22)$ & - & $3.86^{*}$ \\
\hline $\begin{array}{l}\text { Median (min- } \\
\text { max) }\end{array}$ & $7(0-70)$ & $.00(0-23)$ & $5(0-89)$ & & $(2 ; 0.07)$ \\
\hline \multicolumn{6}{|l|}{$\begin{array}{l}\text { Length of service, } \\
\text { years }\end{array}$} \\
\hline Mean (s.d.) & $5(4)$ & $9(5)$ & $6(6)$ & - & $4.68 *$ \\
\hline $\begin{array}{l}\text { Median (min- } \\
\max \text { ) }\end{array}$ & $3(1-19)$ & $7(2-20)$ & $4(1-30)$ & & $(2 ; 0.08)$ \\
\hline
\end{tabular}

$\wedge 7$ cases excluded from analysis due to missing data; +6 cases excluded from analysis due to missing data; ${ }^{*} p<0.05,{ }^{* *} p<0.01$ 
TABLE 3

Comparison of those with pre-service ASB $(n=52)$ with those without pre-service ASB $(n=53)$

\begin{tabular}{|c|c|c|c|c|c|}
\hline Variable & ASB & No ASB & $95 \% \mathrm{Cl}$ & $\chi^{2}$ (OR) & $t$ (d.f) \\
\hline $\begin{array}{l}\text { Left school with no } \\
\text { qualifications, } n(\%)\end{array}$ & $18(35)$ & $9(17)$ & $.154-.966$ & $\begin{array}{l}4.27^{*} \\
(.386)\end{array}$ & - \\
\hline $\begin{array}{l}\text { Convicted of an } \\
\text { offence whilst } \\
\text { serving, } n(\%)\end{array}$ & $25(48)$ & $13(25)$ & $1.24-6.59$ & $\begin{array}{l}6.30 * \\
(2.85)\end{array}$ & - \\
\hline $\begin{array}{l}\text { Experience of } \\
\text { deployment, } n(\%)\end{array}$ & $31(60)$ & $33(62)$ & $.408-1.96$ & $.077(.895)$ & - \\
\hline $\begin{array}{l}\text { Discharged from } \\
\text { service, } n(\%)\end{array}$ & $33(64)$ & $26(49)$ & $.254-1.21$ & $2.21(.554)$ & - \\
\hline $\begin{array}{l}\text { Positive alcohol } \\
\text { misuse screen, } n \\
\text { (\%) }\end{array}$ & $32(62)$ & $27(51)$ & $.709-3.39$ & $1.19(1.54)$ & - \\
\hline $\begin{array}{l}\text { Positive drug } \\
\text { misuse screen, } n \\
\text { (\%) }\end{array}$ & $19(37)$ & 10 (19) & $1.02-6.03$ & $\begin{array}{l}4.10^{*} \\
(2.48)\end{array}$ & - \\
\hline $\begin{array}{l}\text { Positive PTSD } \\
\text { screen, } n(\%)\end{array}$ & $16(62)$ & $10(39)$ & $.773-4.73$ & $1.99(.138)$ & - \\
\hline $\begin{array}{l}\text { Offended before } \\
\text { service^},^{\wedge}(\%)\end{array}$ & $18(39)$ & $11(21)$ & $.983-5.84$ & $3.79(2.40)$ & - \\
\hline $\begin{array}{l}\text { Age, years } \\
\text { Mean (s.d.) } \\
\text { Median (min- } \\
\text { max) }\end{array}$ & $\begin{array}{c}37(10) \\
35(21-56)\end{array}$ & $\begin{array}{c}46(16) \\
44(20-88)\end{array}$ & - & - & $3.48 * *(90)$ \\
\hline $\begin{array}{l}\text { Age at first } \\
\text { conviction^, years } \\
\text { Mean (s.d.) } \\
\text { Median (min- } \\
\text { max) }\end{array}$ & $\begin{array}{c}46(21) \\
19(12-46)\end{array}$ & $\begin{array}{c}52(34) \\
25(14-86)\end{array}$ & - & - & $4.73^{* *}(68)$ \\
\hline $\begin{array}{l}\text { Number of } \\
\text { previous } \\
\text { convictions+ } \\
\text { Mean (s.d.) } \\
\text { Median (min- } \\
\text { max) }\end{array}$ & $\begin{array}{l}13(18) \\
9(0-89)\end{array}$ & $\begin{array}{c}10(18) \\
1(0-81)\end{array}$ & - & - & $-.916(97)$ \\
\hline $\begin{array}{l}\text { Length of service, } \\
\text { years } \\
\text { Mean (s.d.) } \\
\text { Median (min- } \\
\text { max) }\end{array}$ & $\begin{array}{c}5(4) \\
4(1-20)\end{array}$ & $\begin{array}{c}7(6) \\
5(1-30)\end{array}$ & - & - & $2.06(90)$ \\
\hline
\end{tabular}

$\wedge 7$ cases excluded from analysis due to missing data; +6 cases excluded from analysis due to missing data; ${ }^{*} p<0.05,{ }^{* *} p<0.01$ 